\title{
Cutaneous Melanoma pM1b TNM Finding v6
}

National Cancer Institute

\section{Source}

National Cancer Institute. Cutaneous Melanoma pM1b TNM Finding v6. NCI Thesaurus. Code C48868.

Cutaneous melanoma with metastasis to lung. (from AJCC 6th Ed.) 